\title{
PENINGKATAN KUALITAS PEMBELAJARAN IPA MELALUI MODEL PROBLEM BASED LEARNING (PBL) MENGGUNAKAN AUDIOVISUAL
}

\author{
Endang Eka Wulandari, Sri Hartati \\ Jurusan Pendidikan Guru Sekolah Dasar \\ Fakultas Ilmu Pendidikan Universitas Negeri Semarang \\ Email: endangeka7@gmail.com
}

\begin{abstract}
Abstrak
Tujuan Penelitian ini untuk meningkatkan kualitas pembelajaran IPA pada siswa kelas IV melalui model PBL menggunakan audiovisual. Penelitian ini menggunakan desain penelitian tindakan kelas yang berlangsung dalam tiga siklus. Data dianalisis dengan menggunakan teknik analisis deskriptif kuantitatif dan kualitatif. Hasil penelitian menunjukan bahwa (1) Keterampilan guru pada siklus I mendapat skor 18, siklus II skor 22, meningkat pada siklus III skor 25.(2) Aktivitas siswa pada siklus I skor 16,8, pada siklus II skor 22, meningkat menjadi 24,4 pada siklus III. (3) Respon siswa pada siklus I dengan persentase $71 \%$ siklus II dengan persentase $78 \%$, meningkat 92\% pada siklus III (4) Hasil belajar siswa pada siklus I mengalami ketuntasan klasikal sebesar $60 \%$, siklus II sebesar 73\%, dan mengalami peningkatan pada siklus III menjadi 94\%. Kesimpulan penelitian ini menunjukan model $P B L$ menggunakan audiovisual dapat meningkatkan kualitas pembelajaran IPA yang ditandai dengan meningkatnya keterampilan guru, aktivitas siswa, respon siswa dan hasil belajar siswa.
\end{abstract}

Kata kunci: audiovisual; IPA; PBL; kualitas; pembelajaran 


\section{PENDAHULUAN}

Undang-Undang No. 20 Tahun 2003 Pasal 37 Ayat 1 menggariskan program kurikuler Ilmu Pengetahuan Alam (IPA) sebagai muatan wajib kurikulum pendidikan dasar dan pendidikan menengah. Pada jenjang pendidikan dasar dan menengah mata pelajaran IPA harus mencakup beberapa standar kompetensi dan kompetensi dasar. Standar Kompetensi dan Kompetensi Dasar tingkat SD atau MI tertuang dalam Peraturan Menteri Pendidikan Nasional Nomor 22 Tahun 2006 yang isinya tentang standar isi untuk satuan pendidikan dasar dan menengah, bahwa standar kompetensi IPA merupakan standar minimum yang secara nasional harus dicapai oleh peserta didik dan menjadi acuan dalam pengembangan kurikulum di setiap satuan pendidikan.

Hasil refleksi menunjukkan terdapat permasalahan pada saat pembelajaran di kelas IV SDN Kalibanteng Kidul 02 Kota Semarang. Permasalahan tersebut diantaranya guru belum mengawali pembelajaran dengan menyajikan masalah nyata, sehingga siswa kurang terampil dalam memecahkan permasalahan IPA secara ilmiah. Selain itu, antusias siswa dalam pembelajaran masih rendah, guru belum berperan secara optimal sebagai fasilitator dalam menyiapkan alat peraga dan LKS sehingga siswa kesulitan dalam memahami konsep IPA dan mengakibatkan hasil belajar siswa rendah yaitu sebanyak 27 siswa (71\%) belum mencapai nilai KKM yaitu 65.

Peneliti bersama tim kolaborasi berinisiatif menetapkan alternatif tindakan dengan menerapkan pendekatan pembelajaran yang inovatif yang diupayakan dapat meningkatkan kualitas pembelajaran yang meliputi keterampilan guru, aktivitas siswa, respon siswa dan hasil belajar. Salah satu model pembelajaran inovatif yang dapat mengatasi masalah tersebut adalah dengan menerapkan model Problem Based Learning (PBL) dengan media Audiovisual dalam pembelajaran IPA. Melalui penerapan pendekatan PBL dengan media Audiovisual dalam pembelajaran IPA.

Menurut Paul Eggen \& Don Kauchak (2012: 307) Pembelajaran berbasis masalah adalah seperangkat model mengajar yang menggunakan masalah sebagai fokus untuk mengembangkan keterampilan memecahkan masalah, materi dan pengaturan diri. Karakteristik PBL meliputi pelajaran berfokus pada pemecahan masalah, tanggung jawab untuk memecahkan masalah bertumpu pada siswa, guru mendukung poses saat siswa mengerjakan masalah. 
Penelitian terdahulu yang membuktikan bahwa penerapan model PBL dapat meningkatkan kualitas pembelajaran antara lain: Setiyani (2013), Rahmawati,dkk (2013), Nurkhikmah (2013)

Berdasarkan uraian latar belakang maka peneliti mengkaji masalah tersebut melalui Penelitian Tindakan Kelas (PTK) dengan judul "Peningkatan Kualitas Pembelajaran IPA Melalui Model PBL Dengan Media Audiovisual Pada Siswa Kelas IV SDN Kalibanteng Kidul 02 Kota Semarang.

\section{METODE PENELITIAN}

Subyek penelitian yang dilakukan di kelas IV SDN Kalibanteng Kidul 02 Kota Semarang yaitu guru dan siswa sebanyak 38 siswa dengan jumlah 13 siswa laki-laki dan 25 siswa perempuan. Penelitian ini merupakan penelitian tindakan kelas yang setiap siklusnya terdiri dari 4 tahapan yaitu perencanaan, pelaksanaan tindakan, observasi, dan refleksi (Asmani,2011:25). Prosedur PTK ini dilakukan 3 siklus setiap siklusnya terdiri atas 1 pertemuan.

Sumber data penelitian berasal dari guru, siswa, data dokumen, data angket dan catatan lapangan. Metode pengumpulan data menggunakan tes dan nontesmelalui observasi, catatan lapangan, angket dan dokumentasi. Variabel yang diukur dalam penelitian meliputi keterampilan guru, aktivitas siswa, respon siswa, dan hasil belajar siswa.Jenis data yang digunakanyaitu data kuantitatif dan data kualitatif. Teknik analisis data kuantitatif menggunakan teknik analisis deskriptif.

\section{HASIL DAN PEMBAHASAN}

Rekapitulasi hasil peningkatan keterampilan guru, aktivitas siswa, respon siswa, dan hasil belajar siswa disajikan dalam penjelasan berikut ini:

\section{1) Keterampilan Guru}

Keterampilan Guru dari siklus ke siklus mengalami peningkatan hingga siklus terakhir dicapai skor dengan predikat minimal baik pada semua aspek pengamatan. Peningkatan tersebut dapat ditunjukkan pada tabel berikut ini: 
Tabel 1. Rekapitulasi Skor Keterampilan Guru Siklus I, II, dan III

\begin{tabular}{|c|c|c|c|c|}
\hline No & Indikator & Siklus I & Siklus II & Siklus III \\
\hline 1 & Melaksanakan pra pembelajaran & 3 & 4 & 4 \\
\hline 2 & $\begin{array}{l}\text { Mengorientasi } \\
\text { terhadap masalah }\end{array}$ & 2 & 3 & 4 \\
\hline 3 & $\begin{array}{l}\text { Membimbing siswa secara } \\
\text { berkelompok dalam menentukan } \\
\text { subtopik permasalahan }\end{array}$ & 3 & 3 & 3 \\
\hline 4 & $\begin{array}{l}\text { Membimbing siswa untuk aktif } \\
\text { berdiskusi dan melakukan } \\
\text { penyelidikan dalam kelompok }\end{array}$ & 2 & 3 & 3 \\
\hline 5 & $\begin{array}{l}\text { Membimbing siswa } \\
\text { mengembangkan dan menyajikan } \\
\text { hasil karya }\end{array}$ & 2 & 2 & 3 \\
\hline 6 & $\begin{array}{l}\text { Menganalisis dan mengevaluasi } \\
\text { proses pemecahan masalah }\end{array}$ & 3 & 3 & 4 \\
\hline 7 & Menutup pembelajaran & 3 & 4 & 4 \\
\hline \multicolumn{2}{|c|}{ Jumlah Skor } & 18 & 22 & 25 \\
\hline \multicolumn{2}{|c|}{ Rata-rata skor } & 2,57 & 3,14 & $\mathbf{3 , 5 7}$ \\
\hline \multicolumn{2}{|c|}{ Kategori } & Baik(B) & Baik(B) & $\begin{array}{l}\text { Sangat } \\
\text { Baik(A) }\end{array}$ \\
\hline
\end{tabular}

Berdasarkan hasil rekapitulasi keterampilan guru yang terlihat pada tabel 1, skor keterampilan guru pada siklus I, II, dan III secara umum sudah memenuhi indikator keberhasilan yang telah ditetapkan, yakni minimal cukup baik. Selain itu hasil observasi juga menunjukkan bahwa keterampilan guru dalam mengajar meningkat setiap siklusnya. Keterampilan guru dalam mengajar pada siklus I memperoleh persentase sebesar $60 \%$. Persentase keterampilan guru dalam mengajar pada siklus II mengalami peningkatan menjadi 78\%. Persentase keterampilan guru dalam mengajar pada siklus III mengalami peningkatan menjadi $89 \%$.

Keterampilan guru pada setiap indikator mengalami peningkatan sehingga pembelajaran dapat dikatakan berhasil. Meliputi mengkondisikan siswa untuk mengikuti pembelajaran guru menarik perhatian siswa dengan menggunakan media audiovisual. kegiatan mengorientasi peserta didik terhadap masalah. guru memberikan pertanyaan yang menarik perhatian siswa dengan mengaitkan pertanyaan dengan kehidupan sehari-hari siswa. kegiatan membimbing siswa secara berkelompok dalam menentukan subtopik permasalahan, guru memberikan petunjuk jalannya diskusi dan prosedur pembelajaran sesuai dengan perencanaan 
penggunaan alat dan bahan. kegiatan menyajikan dan mengembangkan hasil karya guru harus mampu mengelola kelas dengan baik. Pada kegiatan menganalisis dan mengevaluasi proses pemecahan masalah guru menyempurnakan jawaban dari hasil penyelidikan, kemudian guru mengajak siswa untuk membuat kesimpulan hasil percobaan yang dilakukan. Kegiatan menutup pembelajaran, guru memberikan refleksi atau penguatan materi terhadap hasil kerja siswa.

Hal ini didukung dengan selama proses pembelajaran guru sudah menerapkan 8 keterampilan dasar mengajar (Mulyasa, 2013: 84), yaitu keterampilan membuka dan menutup pelajaran pembelajaran, keterampilan bertanya, keterampilan memberi penguatan, keterampilan menjelaskan, keterampilan mengadakan variasi, keterampilan membimbing diskusi kelompok kecil, mengelola kelas, dan keterampilan mengajar kelompok kecil dan perorangan.

\section{2) Aktivitas Siswa}

Peningkatan aktivitas siswa siklus I, II, dan III dalam pembelajaran IPA dengan model PBL dengan media audiovisual pada siswa kelas IV ditunjukkan pada tabel berikut ini:

Tabel 2. Rekapitulasi Skor Aktivitas Siswa Siklus I, II, dan III

\begin{tabular}{clccc}
\hline No & \multicolumn{1}{c}{ Indikator } & Siklus I & Siklus II & Siklus III \\
\hline 1 & $\begin{array}{l}\text { Menyimak materi pengantar oleh } \\
\text { guru }\end{array}$ & 2,10 & 3,00 & 3,40 \\
2 & $\begin{array}{l}\text { Mengamati tayangan materi pada } \\
\text { media audiovisual }\end{array}$ & 2,50 & 3,20 & 3,50 \\
3 & $\begin{array}{l}\text { Melaksanakan tugas pemecahan } \\
\text { masalah secara berkelompok }\end{array}$ & 2,70 & 3,30 & 3,70 \\
4 & $\begin{array}{l}\text { Menganalisis informasi/data } \\
\text { yang diperoleh dan melakukan } \\
\text { eksperimen untuk menguji }\end{array}$ & 3,20 & 3,50 & 3,80 \\
$\quad \begin{array}{l}\text { hipotesis } \\
\text { Menyajikan hasil analisis dalam } \\
\text { bentuk laporan }\end{array}$ & 2,40 & 3,20 & 3,30 \\
$\quad \begin{array}{l}\text { Melakukan evaluasi terhadap } \\
\text { proses pemecahan masalah }\end{array}$ & 1,80 & 2,70 & 3,20 \\
$\quad \begin{array}{l}\text { Melakukan refleksi terhadap } \\
\text { kegiatan yang telah dilakukan }\end{array}$ & 2,10 & 3,10 & 3,50 \\
\hline $\begin{array}{l}\text { Jumlah Skor } \\
\text { Rata-rata skor }\end{array}$ & $\begin{array}{l}16,80 \\
\text { Kategori }\end{array}$ & $\begin{array}{l}2,40 \\
\text { Cukup(C) }\end{array}$ & $\begin{array}{c}\text { Baik(B) } \\
\text { Sangat Baik } \\
\text { (A) }\end{array}$ \\
\hline
\end{tabular}


Berdasarkan hasil rekapitulasi aktivitas siswa yang terlihat pada tabel 2, skor aktivitas siswa pada siklus I, II, dan III secara umum sudah memenuhi indikator keberhasilan yang telah ditetapkan, yakni minimal baik. Selain itu hasil observasi juga menunjukkan bahwa aktivitas siswa meningkat setiap siklusnya. Aktivitas siswa pada siklus I memperoleh persentase $60 \%$. Perolehan persentase aktivitas siswa pada siklus II mengalami peningkatan menjadi 78,57\%. Perolehan persentase aktivitas siswa pada siklus III mengalami peningkatan menjadi 87,14.

Aktivitas siswa pada setiap indikator mengalami peningkatan sehingga pembelajaran dapat dikatakan berhasil. Meliputi aktivitas siswa menyimak penyampaian materi pengantar dari guru sudah baik saat mengikuti pembelajaran sebagian siswa memperhatikan penjelasan dan penyampaian materi oleh guru dengan tertib dan konsentrasi. Aktivitas siswa dalam mengamati tayangan materi pada media audiovisual sudah baik karena semua siswa memperhatikan audio visual yang ditampilkan guru dan mencatat informasi yang penting saat memperhatikan media.

Aktivitas siswa dalam melaksanakan tugas pemecahan masalah secara berkelompok sudah baik, karena siswa ikut menyampaikan ide-ide dan berpendapat untuk memecahkan masalah, sehingga keberhasilan dalam pemecahan masalah pun tercapai. Aktivitas menganalisis informasi/ data yang diperoleh dan melakukan eksperimen untuk menguji hipotesis sudah baik karena siswa dalam melakukan kegiatan menemukan pengetahuan baru melalui alat peraga sudah lebih baik. Aktivitas siswa dalam menyajikan hasil analisis dalam bentuk laporan sudah baik karena siswa sudah dapat menuangkan hasil penyelidikan ke dalam lembar kerja kelompok. Aktivitas melakukan evaluasi terhadap proses pemecahan masalah sudah baik karena siswa dapat mengkritisi proses pemecahan masalah kelompok lain. Aktivitas siswa dalam melakukan refleksi terhadap hasil pembelajaransudah baik, karena siswa dapat menyimpulkan hasil pembelajaran dengan bimbingan guru.

Menurut Usman (2013: 22) aktivitas belajar meliputi aktivitas jasmaniah maupun aktivitas mental. Aktivitas fisik dan psikis harus memiliki keterkaitan dalam kegiatan belajar. Hal ini bertujuan agar hasil pembelajaran menjadi lebih optimal. Aktivitas fisik ialah aktivitas siswa yang melibatkan anggota badan, bergerak dan tidak hanya pasif termasuk membuat sesuatu, ia tidak hanya duduk dan mendengarkan dan melihat. Peserta didik yang memiliki aktivitas psikis adalah, jika daya jiwa peserta didik difungsikan secara maksimal dalam rangka pengajaran. 


\section{3) Respon Siswa}

Peningkatan aktivitas siswa siklus I, II, dan III dalam pembelajaran IPA dengan model PBL dengan media audiovisual pada siswa kelas IV ditunjukkan pada tabel berikut ini:

Tabel 3. Rekapitulasi Respon Siswa Siklus I, II, dan III

\begin{tabular}{|c|c|c|c|c|c|c|c|}
\hline \multirow{2}{*}{ No } & \multirow{2}{*}{ Pertanyaan } & \multicolumn{2}{|c|}{ Siklus I } & \multicolumn{2}{|c|}{ Siklus II } & \multicolumn{2}{|c|}{ Siklus III } \\
\hline & & Ya & Tidak & Ya & Tidak & $\mathbf{Y a}$ & Tidak \\
\hline 1 & $\begin{array}{l}\text { Apakah anda senang dengan } \\
\text { cara mengajar Ibu tadi ? }\end{array}$ & $71 \%$ & $29 \%$ & $78 \%$ & $22 \%$ & $92 \%$ & $8 \%$ \\
\hline 2 & $\begin{array}{l}\text { Apakah media yang Ibu } \\
\text { gunakan tadi menarik? }\end{array}$ & $76 \%$ & $24 \%$ & $84 \%$ & $16 \%$ & $94 \%$ & $6 \%$ \\
\hline 3 & $\begin{array}{l}\text { Apakah anda paham dengan } \\
\text { materi yang Ibu sampaikan? }\end{array}$ & $57 \%$ & $43 \%$ & $65 \%$ & $35 \%$ & $84 \%$ & $16 \%$ \\
\hline 4 & $\begin{array}{l}\text { Apakah dengan } \\
\text { menggunakan media } \\
\text { audiovisual tadi, anda lebih } \\
\text { mudah memahami materi? }\end{array}$ & $63 \%$ & $37 \%$ & $76 \%$ & $24 \%$ & $94 \%$ & $6 \%$ \\
\hline 5 & $\begin{array}{l}\text { Apakah anda mau belajar } \\
\text { lagi dengan menggunakan } \\
\text { cara mengajar Ibu seperti } \\
\text { tadi? }\end{array}$ & $84 \%$ & $16 \%$ & $86 \%$ & $14 \%$ & $97 \%$ & $3 \%$ \\
\hline \multirow{2}{*}{\multicolumn{2}{|c|}{$\begin{array}{l}\text { Rata-rata Persentase } \\
\text { Kategori }\end{array}$}} & $71 \%$ & $29 \%$ & $76 \%$ & $22 \%$ & $92 \%$ & $8 \%$ \\
\hline & & \multicolumn{2}{|c|}{ Positif } & \multicolumn{2}{|c|}{ Positif } & \multicolumn{2}{|c|}{$\begin{array}{l}\text { Sangat } \\
\text { Positif }\end{array}$} \\
\hline
\end{tabular}

Berdasarkan hasil rekapitulasi respon siswa yang terlihat pada tabel 3, persentase respon siswa pada siklus I, II, dan III secara umum sudah memenuhi kategori keberhasilan yang telah ditetapkan, yakni minimal Positif. Selain itu hasil observasi juga menunjukkan bahwa respon siswa meningkat setiap siklusnya. Respon siswa pada siklus I memperoleh persentase $71 \%$. Perolehan persentase respon siswa pada siklus II mengalami peningkatan menjadi $78 \%$. Perolehan persentase respon siswa pada siklus III mengalami peningkatan menjadi $92 \%$. Sehingga, pembelajaran IPA menerapkan model Problem Based Learning dengan media audiovisual dapat meningkatkan respon siswa dan minat siswa terhadap pembelajaran yang dilaksanakan, memancing rasa ingin tahu siswa yang tinggi yang berdampak pada aktivitas siswa pada pembelajaran meningkat dan hasil belajar siswa pun meningkat.

4) Hasil Belajar

Peningkatan hasil belajar siswa kelas IV ditunjukkan pada tabel berikut ini: 
Tabel 4. Rekapitulasi Hasil Belajar Siswa Siklus I, II, dan III

\begin{tabular}{ccccc}
\hline No & Pencapaian & Siklus I & Siklus II & Siklus III \\
\hline 1 & Rata-rata & 70 & 74 & 79,3 \\
2 & Nilai terendah & 30 & 32 & 38 \\
3 & Nilai tertinggi & 96 & 98 & 100 \\
4 & Belum tuntas & 12 & 10 & 2 \\
5 & Tuntas & 26 & 28 & 36 \\
6 & Persentase Ketuntasan & $69 \%$ & $73 \%$ & $94 \%$ \\
\hline
\end{tabular}

Data pada tabel 4 menunjukkan bahwa perolehan hasil belajar ranah kognitif pada siklus I dan II belum memenuhi indikator keberhasilan yang ditetapkan.Namun, pada siklus III sudah memenuhi indikator keberhasilan yang telah ditetapkan yaitu ketuntasan klasikal minimal 80\% terpenuhi.Selain itu juga dapat dilihat bahwa terjadi peningkatan hasil belajar setiap siklusnya. Hal tersebut ditunjukkan karena adanya peningkatan persentase hasil belajar kognitif yang naik setiap siklus. . Pada siklus I $31 \%$ anak belum mencapai KKM yaitu 65. Pada siklus II 27\% anak belum mencapai KKM. Pada siklus III 6\% anak belum mencapai KKM.

Penelitian sebelumnya oleh Mohamad (2011) menunjukkan bahwa evaluasi diri dalam pembelajaran PBL dapat meningkatkan kinerja diri. Tahir (2011) menunjukkan bahwa model PBL dapat meningkatkan infrastruktur pendidikan denganmengkaji tempat dan ruang belajar dalam pendidikan teknik.Nalliveettil(2013) menemukan bahwa audiovisual dapat menghemat waktu dan tenaga kerja daritenaga pengajar. Eliyana (2014) menyatakan bahwa model pembelajaran PBLdapat meningkatkan hasil belajar siswa pada materi keliling dan luas. Farkhatus (2012) penggunaan media audiovisual meningkatkan proses dan hasil belajar siswa. Agustin (2013) model pembelajaran PBL meningkatkan Aktivitas siswa dan hasil belajar matematika.Utami (2013) menunjukan bahwa penggunaan audiovisual dapat meningkatkan pemahaman konsep siswa di sekolah dasar.Didalam penelitian ini terbukti bahwa model $P B L$ menggunakan audio visual juga dapat meningkatkan hasil belajar siswa pada pembelajaran IPA.

Berdasarkan penelitian yang telah dilakukan, terlihat bahwa terjadi peningkatan keterampilan guru, aktivitas siswa, hasil belajar siswa pada pembelajaran IPA di kelas IV. Hal ini membuktikan bahwa penerapan model $P B L$ dengan media audio visual merupakan salah satu upaya yang efektif untuk meningkatkan kualitas pembelajaran IPA di SD. Hal itu disebabkan karena model $P B L$ adalah model yang menuntut siswa agar bertanggung jawab terhadap tugas 
yang di terima dikarenakan siswa akan menjelaskan tugas yang menjadi tanggung jawabnya pada teman satu kelompok. Melalui model $P B L$ menggunakanaudiovisual meningkatkan keterlibatan siswa secara aktif dalam proses pembelajaran. Hal itu berakibat pada pengetahuan yang didapatkan siswa menjadi lebih bermakna dan berdampak pada meningkatnya hasil belajar siswa.

\section{KESIMPULAN}

Berdasarkan hasil pembahasan, disimpulkan bahwa melalui penerapan model $P B L$ menggunakanaudiovisual di kelas IV SDN Kalibanteng Kidul 02Kota Semarang dapat meningkatkan kualitaspembelajaran IPA.Peningkatan kualitas pembelajaran tersebut ditunjukkan dengan meningkatnya keterampilan guru, aktivitas siswa, respon siswa, dan hasil belajar siswa. 


\section{DAFTAR PUSTAKA}

Agustin. 2013. "Peningkatan Aktifitas dan Hasil Belajar Siswa Melalui Model Problem Based Learning (PBL)". Semarang: e-journal UNNES. Jurnal. 2(1):36-44

Asmani, Jamal M. 2011. Penelitian Tindakan Kelas. Jogjakarta: Laksana.

Eggen, Paul. 2012. Strategie and Models for Teacher: Teaching Content and Thinking Skills, Sixth Edition. Boston: Pearson Education, Inc.

Eliyana. 2014. "Keefektifan Model Problem Based Learning Terhadap Hasil Belajar Keliling Dan Luas". E-Journal UNNES. Jurnal. 3,(1):40-45

Farkhatus, Solikhah,dkk. 2012. Penerapan Strategi LSQ Berbantuan Media Audio Visual Untuk Meningkatkan Hasil Belajar Ekonomi.Jurnal. Semarang : Universitas Negeri Semarang. Jurnal. 1, (2): 315-322

Herrhyanto. 2008. Statistika Dasar. Jakarta: Universitas Terbuka.

Mathew, Nalliveettil George dan Ali Odeh Hammoud Alidmat. 2013. A Study on the Usefulness of Audio-Visual Aids in EFL Classroom:Implications for Effective Instruction. International Journal of Higher Education. Jurnal. 1, (3): 392-399

Mohamad, dkk. 2011. Self-Evaluation In Problem-Based Learning. Universiti Kebangsaan Malaysia. Jurnal. 3, (1): 50-57

Nurkhikmah. 2013."Keefektifan Penerapan Model Problem Based Learning (PBL) Terhadap Peningkatan Kualitas Pembelajaran IPA”. Semarang: e-journal UNNES. Jurnal.2, (2):19-24

Rahmawati,dkk (2013) dengan judul "Peningkatan Kualitas Pembelajaran Geometri Melalui Kepala Bernomor Terstruktur Berbantuan Media Audio Visual". Semarang: e-journal UNNES.Jurnal. Jurnal. 2, (3): 10-17

Setiyani, (2013) dengan judul "Peningkatan Kualitas pembelajaran IPS menggunakan Snowball Throwing media audiovisual kelas IV”. E-journal UNNES. Jurnal. . 2, (3): 70-77

Tahir, dkk. 2011. Constructing Place And Space In The Design Of Learning Environments For Pbl In Malaysian Universities. Universiti Kebangsaan Malaysia. Jurnal. 1, (1): 26-34

Utami, Kurnia. 2013. Penggunaan Media Audio Visual Untuk Meningkatkan Pemahaman Konsep Siswa Di Sekolah Dasar. Jurnal. Surabaya: Universitas Negeri Surabaya. Jurnal. 2, (3): $77-84$ 